\title{
Raymond A. Bauer: A Pioneer in the Use of Sample Surveys to Assess Quality of Life
}

\author{
Adrian J. Tomyn ${ }^{1,2}$
}

Received: 17 April 2015 /Accepted: 18 April 2015 /Published online: 29 April 2015

(C) Springer Science+Business Media Dordrecht and The International Society for Quality-of-Life Studies

(ISQOLS) 2015

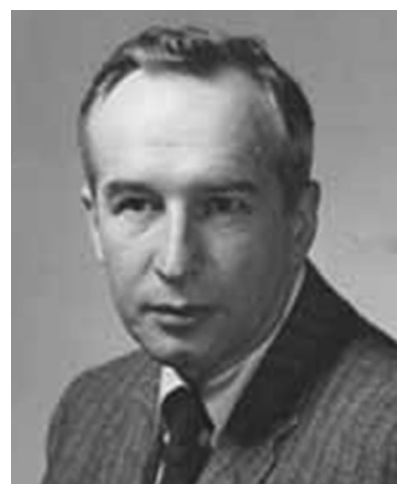

Raymond Augustine Bauer (1916-1977) was a Pioneer of the social Indicators movement who symbolized the best in the use of sample surveys in conducting quality of life and well-being research. The movement itself emerged in the United States in the mid 1960's, in response to NASA's interest in measuring and monitoring the impact of the American Space Program on U.S. society and its citizens. Asked by NASA to design and lead a national social indicators research program, Bauer set out to define and quantify a basic set of qualities and characteristics that reflect society, and to obtain a reading on where society was in relation to them. Stemming from his work with NASA, Bauer is well known as the editor of the seminal book 'Social Indicators' (1966), which outlines the importance of using research and statistics to help "assess where we stand and are going with respect to our values and goals”. Social Indicators

Adrian J. Tomyn

adrian.tomyn@gmail.com

1 School of Psychology, Counseling and Psychotherapy, Cairnmillar Institute, Melbourne, Australia

2 School of Psychology, Deakin University, Melbourne, Australia 
was the preeminent book of its time and brought together a broad range of scholars representing many social science disciplines and all regions of the world. They shared a common belief in the importance of social indicators in helping to shape public policy in influencing the well-being of citizens locally, nationally and, in many cases, internationally. Many of the contributors to this volume went on to be becoming social indicators researchers in their own right and many already have been identified as Pioneers in the pages of this journal. Bauer's pioneering work led to the belief that social indicators, defined at the time largely in terms of quantifiable economic outcomes, should be the foundation for all aspects of public and private policy making in helping to both anticipate and respond to the consequences of the very rapid technological and information changes occurring in all economically advanced nations.

Raymond Bauer was born on September 7, 1916 in Chicago, Illinois. He received his BS from Northwestern University in 1943 and later went on to complete both his MA (1948) and PhD (1950) degrees from Harvard University. As a graduate student, he was a Fellow in Harvard's Russian Research Center. After earning his doctorate he taught social relations at Harvard until 1953 whereupon he left Harvard to teach at MIT's Center for International Studies. In 1955 he became a Fellow of MIT's Center for Advanced Study in Behavioral Science. He returned to Harvard in 1957 as Professor of Business Administration in the Harvard Business School. In 1970, Professor Bauer left briefly to work at the White House as the Senior Consultant to the Presidentiallyappointed National Goals Research Staff where he contributed to a published a report entitled, "Toward a Balanced Growth Quantity with Quality." In 1974 Professor Bauer became the first Joseph C. Wilson Professor of Business Administration at Harvard, a position he kept until his death in July 1977.

Professor Bauer received many awards over his long and distinguished career. In 1964, for example, he, along with Ithiel de Sola Pool and Lewis Anthony Dexter, won the Woodrow Wilson Foundation Book Award for their book, American Business and Public Policy. He was also awarded the American Association for Public Opinion Research Award for Exceptionally Distinguished Achievement in 1975, just two years prior to his death.

Professor Bauer served on many committees and associations. He was a member of the American Association of Advertising Agencies, the American Association for Public Opinion Research, the American Psychological Association, the Massachusetts Psychological Association, the National Academy of Sciences/National Research Council, the American Academy of Arts and Sciences, and many others. He also counted hundreds of graduate students among the many lives that his academic brilliance and personal warmth provided inspiration to.

Raymond Bauer wrote fifteen books in addition to more than 100 articles. His citations number in the hundreds of thousands and are reflected in the literatures of political science, sociology, sampling methodology and survey research, as well as social science research more broadly. His publications deal with such diverse subjects as Soviet Psychology, advertising and consumer behavior, the policy making process in government, the social responsiveness of corporations, quality of life and well-being, as well as the conceptualization and methodology of creating reliable social indicators for use at various levels of analysis.

Raymond Bauer was a true Pioneer in all aspects of theoretical and applied quality of life research and was a man who's work inspired and entire field of intellectual inquiry. 
Acknowledgments The author would like to acknowledge Harvard Business School Archives for providing their permission to use the Raymond A. Bauer Papers in preparation of this article.

\section{References}

Bauer, R. A. (Ed.). (1966). Social indicators. Cambridge: The M.I.T. Press.

Bauer, R.A. (1916-1977) Papers Harvard Business School Archives. Baker Library Historical Collections. Harvard Business School. 